\title{
Perceptions and Emotions of Nursing Students in View of Death
}

\author{
Larissa Rodrigues ${ }^{1}$ and Ana Catarina Araújo Elias ${ }^{2}$ \\ ${ }^{1}$ Nurse, PhD student in Medical Sciences at the State University of Campinas in Campinas, Brazil \\ ${ }^{2}$ Psychologist, Doctor in Medical Sciences at the State University of Campinas in Campinas, Brazil
}

Submission: January 30, 2020; Published: March 04, 2020

*Corresponding author: Larissa Rodrigues Rui Barbosa Street, 1836, Salto, SP - Brazil

\begin{abstract}
The aim of this study was to evaluate the nursing student's education in relation to death and terminal emotions. The research subjects were 21 students from the last period of the undergraduate nursing course of a college in the countryside of São Paulo. Some students were randomized to answer a semi-structured questionnaire consisting of 6 open-ended questions and a Visual Analog Scale (VAS). The following analyzes were performed: content thematic analysis and quantitative by the statistical modality. We found categories in each question and indicated a maximum of 4 types of profile among students, ranging from $33 \%$ to $78 \%$ who felt prepared or ready to face work with death and knew the goals of palliative care. The percentage of students who did not feel prepared and considered the approach to palliative care in the undergraduate course varied from $5 \%$ to $43 \%$. The uncomfortable intensity of feelings about death prevailed among the students. So, greater importance to palliative care is required during the undergraduate nursing course. The lack of practice of palliative care is evident and a clinical practice stage in palliative care should be inserted, as the experience can bring students' emotions and provoke the necessary discussion for the theme.
\end{abstract}

Keywords: Academic; Palliative care; Nursing, Death

\section{Introduction}

When one leaves the 'obstinacy for the cure' in detriment of the 'fullness of life', there is a move towards a paradigm change related to health care at a time when, without too much aggression to the body that cannot have the living conditions restored, it is necessary to train nurses in palliative care [1]. The perspective of insidiously extinguishment of life enables the adoption of a reflective posture, with review of concepts and paradigms by those who experience the proximity of death, whether patients, family or health professionals [2]. Prolonging the dying process brings unnecessary psychological, emotional and physical suffering and makes death seem an invader, something far distinct from that naturally enduring being. Instead of rest and peace, they receive devices, bites, probes and catheters, among other invasive procedures, because health professionals are concerned about organs, pulsations and other parameters and not with the person who is afraid of dying [3].

In order nurses can act as a link between the parties and provide comfort, environmental safety, individuality and quality of life for the patient until the last moment of his life, it is necessary to be prepared, to study and develop their psychological and emotional issues, becoming subtle and firm in their positioning in relation to the patients' issues and their treatment $[4,5]$. Knowing how to act is to be aware of the technical-scientific procedure and prepared to elaborate one's own emotions and assist in the elaboration of the emotions of others. "Nursing and medical schools must prepare professionals so that, besides being technically competent, they are able to deal with their own feelings and use them in a deliberate and humanly sophisticated way" [6].

The aim of this study was to evaluate the nursing undergraduate education in the final period of the undergraduate course regarding death, as well as to identify the student's perception and emotions about the terminality of life.

\section{Method}

The subjects of this research were 21 students from the last period of the undergraduate nursing course at a college in the state of São Paulo, Brazil. The sample calculation was performed 
by the statistical service of the Institution where the research was carried out. The selection of subjects was randomized, and all responded to a semi-structured questionnaire composed of 6 open questions and a Visual Analogue Scale (VAS), to measure the intensity of their feelings about death. After being informed, the subjects signed an Informed Consent Form (ICF); the survey was limited to a questionnaire, with no experiments. The study was approved by the local Research Ethics Committee under number $1038 / 2006$.

When adopting the phenomenological approach, the qualitative evaluation of the data collected in the field was obtained through the thematic content analysis carried out by the two authors of the research $(7,8)$, associated with the descriptive method, and also with the statistical mode, to proceed to the evaluation quantitative (9). A questionnaire was not returned, and this resulted in loss of the sample, making up the final sample with 20 questionnaires analyzed.

\section{Results}

First question: What is your perception about the finitude of the human being and about your own finitude? Four categories of answers were found: $35 \%$ of the undergraduates pointed man as the center of existence, expressed willingness to accomplish great deeds throughout life and feared death would interrupt them; $40 \%$ of them understood life as a cycle and death as a transformation, considering the human being as part of nature; $20 \%$ considered death to be a fresh start and life as a training when people perform tasks that would be evaluated, and they feared the afterlife; $5 \%$ believed that death to be a choice of each human being as life depends on energy in which the death of the body does not represent the end of that energy.

Second question: What is the expectation about nurse's role in the process of acceptance of death by the patients? What do you understand by palliative care? There were 4 categories of answers: $80 \%$ of students understood palliative care as a way of providing dignity, relief and comfort for the patient; $5 \%$ affirmed that palliative care was synonymous of civility; $10 \%$ understood terminality as suffering and they feared the patient would refuse their care; $5 \%$ answered they did not understand the nurse's relationship with the patient regarding terminality.

Third question: Do you feel prepared for a relationship with patients with dark prognosis? How do you feel after the death of one of them or how do you think you will feel? There were only 2 categories of answers: $55 \%$ felt prepared to interact with terminally ill patient, they got involved in the relationship and expressed sadness and grief for the patients' death; and 45\% felt unprepared for the relationship, they were afflicted with what they might feel at that moment; they sought knowledge, felt themselves helpless and frustrated and showed desire to escape from the communication with the patient.
Fourth question: Can you identify some of the stages of the process described by Kübler-Ross? Which one of them? In what environment? Three categories of answers were found: $25 \%$ of the students knew the phases described by the author and were able to identify them in the patients, mainly the phase of denial, anger and acceptance; $40 \%$ of them knew the author and mentioned parts of her work but did not report the use of any of the author's practice with patients; and 35\% did not know the author or remembered having studied her work.

Fifth question: What do you understand by psychological and spiritual support? Were these skills approached in the undergraduate training? How about other skills required in this context? It was possible to describe 4 categories of answers: $50 \%$ of the undergraduates considered that the psychological support was in the environment, the spiritual support was within the patient, they respected the individuality of beliefs, and they also considered these aspects were contemplated along the undergraduate training ; 30\% regarded psychological support as supplied by the home environment, respected and stimulated beliefs and did not mention any approach to these topics during the undergraduate course; $15 \%$ distinguished psychological from spiritual support and considered the approach offered at the undergraduate course as insufficient; $5 \%$ understood both services as only one and reported those as often mentioned throughout undergraduate training.

Sixth question: In your conception what is meaning of life? What feeling and emotion do you experience when you reflect on death? There were 3 categories of answers: $60 \%$ of the students identified life as a gift offered by someone; $15 \%$ addressed the reflections to moments already lived by them; $25 \%$ found the life itself challenging and intended to be intense and present.

Seventh question is related to the intensity of feelings when reflecting upon death, using the Visual Analog Scale (VAS) model of colored faces: no student pointed the blue color (no intensity), 4 students pointed blue green color (light intensity), 3 students identified the color green (moderate intensity), 10 undergraduates chose the color yellow (uncomfortable sensation), colors orange (intense) and red (unbearable) were selected by 1 academic and 1 of them did not report intensity on the scale.

\section{Discussion}

In the first question the assessment drawn through the statistic mode reveals that most students need to overcome death with their lifelong accomplishments and to believe in the continuity of man even after death. They are only anguished when thinking about the limited time of material life, which points to the Freudian theory about the energy of life [7]. In the first question, the assessment by the statistical mode reveals that most students must overcome death with their lifelong achievements and believe in the continuity of man, even after death. They are 
distressed to think of the limited time of material life, which suggests Freud's theory of the energy of life. The organism wishes to die in its own way, the time has come for the exhaustion of life energy, for the organism's intriguing determination to maintain its own existence in the face of all obstacles is no longer met [8].

Between the two main groups, the striking difference is that the largest group (40\%) understands man as the most important part of nature and the other group (35\%) understands man as an integral part of nature of relative importance. The second and third questions can be discussed together as while in the second question a very significant percentage of students (80\%) report the cognitive absorption of the concept of palliative care and the role of nurses in this care, in the third question these students are divided between those who feel prepared to practice with the patient (55\%) and those who feel insecure and unprepared (45\%). It appears that personal issues interfere with the clarity of attitudes and practice of the profession, and this requires attention for a good performance of the nursing staff. The nurse, as a leader who acknowledges theory yet is not able to demonstrate and organize the practice, can be harmful to the team he/she leads.

Concern about the involvement between knowledge and practice can be explained by the tendency to escape situations that lead us to failure when, in an attempt to protect ourselves from feelings of fear and guilt when it is no longer possible to prevent a bad outcome [9]. In the fourth question there is a division in three groups. All groups show significant number of students who have cognitively absorbed the content but have difficulty to explain it, showing some personal barrier related to death; students who make it clear that they have absorbed the content and strive to explain and identify it in the internship; and still a large group that refuses to explain the content, suggesting the denial of death itself. Such partial or total denial comes from the ego that elaborates defense mechanisms and "it is emphasized that the more immature and less developed the ego is, the more primitive and magical the defenses (omnipotence, denial, idealization, projection and introjection, among others). Similarly, the more evolved the ego, new and more organized defenses will be used, such as repression, rationalization and sublimation, among others [10].

In the fifth question, the statistics mode points to a prevailing category in which $50 \%$ of the students make a clear distinction between spiritual and psychological support as well how to provide them to the patient. However, in the other categories that also add up to $50 \%$, the students were confused about the content, which makes it difficult to prescribe and perform support care to the patient because if the team is to be directed by a confused leader, the misconception will be extended to all other members. According to the remaining students a theoretical approach of these topics is provided along the undergraduate nursing training. Thus, we can restate the hypothesis of personal blockage causing the misunderstanding. The character of team leadership is expressed in the statement: "Initially the member of a group identifies with the leader and, in a second moment, with the other members of the group. This dynamic is possible as each one renounces to the individual egoistic ideal [11]. Then, the members of the group replace their egoistic ideals by the same figure, the leader. Team cohesion is granted by the reciprocal identification between different egos [12].

In the sixth question, statistics mode reveals that $60 \%$ of the students have experienced fear and distress when reflecting upon finitude. The discomfort regarding death is pointed out by VAS by $50 \%$ of the students, showing it has an impact in their daily life, even outside the work environment. The lack of ideal care with terminal patients remains evident. Thus, the practice in palliative care should be implanted even in non-specialized hospitals to achieve the ideal. As found in the testimonials of this group, only experience brings to conscience the emotions and sensations involved in this field. When the feelings and emotions facing death emerge, they can be worked out and integrated with the theoretical content of the nursing qualification, through strategies that provide space for the students to express their minds and exchange their thoughts about them. This include learning therapies for pain relief and psychological and spiritual support with patients and their families and caregivers $[9,13]$

The study showed that most students have a cognitive understanding regarding palliative care and how to perform tasks related to it. However, the qualification of nursing students needs to be improved regarding the elaboration of personal issues and development of emotional maturity in order to apply these skills competently. The attitude of the leading nurse in shaping his team to administer palliative care also seems to raise some questions among the students. Thus, better preparation is required regarding this aspect since noticeable sensitivity and willingness with respect to team management in palliative care can be found in most students. Considering the testimonials given by the nursing undergraduates, it is evident that palliative care should receive greater acknowledgment throughout nursing training, and that the content covered by the institution did not meet the learning needs of the students.

\section{Conclusion}

Taking the testimonials of the students into consideration, it was possible to affirm that the undergraduate course should give a greater importance to palliative care. There was no relevant difference among the sixteen (16) students with experience in working with patients and the four (4) students without experience, yet there is an intensification of feelings and reactions such as escape, fear and anguish in the last four students. Therefore, it is possible to state that only working with palliative care patients and their forthcoming death do not offer enough preparation to deal properly with death and the process of dying. 
The lack of care practice with terminal patient is evident and an internship in palliative care could be inserted, even in nonspecialized hospitals, because only the experience can bring the emotions and sensations as reported. The emerging of these feelings can be worked out along with the palliative care technique and open to the testimonials of the students and discussions about them, as well as the application of pain relief therapies and psychological and spiritual support to patients, relatives and caregivers.

\section{Acknowledgement}

Language help by Audrey Vendramini.

\section{References}

1. Gysels M, Evans CJ, Lewis P, Speck P, Benalia H, et al. (2013) MORECare research methods guidance development: recommendations for ethical issues in palliative and end-of-life care research. Palliat Med 27(10): 908-917.

2. Arco C, Ferrari CMM, Carvalho LVBd, Priel MR, Pereira LL (2016) Obstinação terapêutica sob o referencial bioético da vulnerabilidade na prática da enfermagem. Mundo saúde (Impr) 40(3): 382-389.

3. Zorzetti RCS, Manfro PHG, Ramos LdA (2018) Processo de perdas e morte em cuidados paliativos: paciente, família e equipe assistente. Acta méd (Porto Alegre) 39(2): 356-369.

4. Rolim DS, Arboit ÉL, Kaefer CT, Marisco NdS, Ely GZ, Arboit J (2019) Produção científica de enfermeiros brasileiros sobre enfermagem e oncologia: revisão narrativa da literatura. Arq ciências saúde UNIPAR 23(1): 41-47.
5. Silva HAd, Viana GKB, Lima AKG, Lima ALAd, Mourão CML (2018) Intervenção em cuidados paliativos: conhecimento e percepção dos enfermeiros. Rev enferm UFPE online 12(5): 1325-1330.

6. Guimarães VC, Celes LAM (2007) O psíquico e o social numa perspectiva metapsicológica: o conceito de identificação em freud. Psicol teor pesqui 23(3): 341-346.

7. Azevedo MK, Neto GARM (2015) O desenvolvimento do conceito de Pulsão de Morte na obra de Freud. Rev Subj (Impr) 15(1): 67-75.

8. Freud S, Luto e Melancolia (1996) Edição standard brasileiradas obras psicológicas completas de Sigmund Freud. (14 ${ }^{\text {th }}$ Edtn) Rio de Janeiro.

9. Elias ACA, Ricci MD, Rodriguez LHD, Pinto SD, Giglio JS, et al. (2015) The biopsychosocial spiritual model applied to the treatment of women with breast cancer, through RIME intervention (relaxation, mental images, spirituality). Complement Ther Clin Pract 21(1): 1-6.

10. Alves CB, Dulci PL (2014) Quando a morte não tem mais poder: considerações sobre uma obra de Elisabeth Kübler-Ross. Rev bioét (Impr) 22(2): 262-270.

11. Elias ACA (2010) Trauma e superação: o que a psicologia, a neurociência e a espiritualidade ensinam. Aletheia (31): 212-214.

12. Green V (2013) Grief in two guises: 'Mourning and melancholia' revisited. Journal of Child Psychotherapy 39(1): 76-89.

13. Elias ACA, Ricci MD, Rodriguez LHD, Pinto SD, Giglio JS, et al. (2017) Development of a Brief Psychotherapy modality entitled RIME in a hospital setting using alchemical images. Estud Psicol (Campinas, Online) 34(4): 534-547.

Your next submission with Juniper Publishers will reach you the below assets

- Quality Editorial service

- Swift Peer Review

- Reprints availability

- E-prints Service

- Manuscript Podcast for convenient understanding

- Global attainment for your research

- Manuscript accessibility in different formats

( Pdf, E-pub, Full Text, Audio)

- Unceasing customer service

Track the below URL for one-step submission

https://juniperpublishers.com/online-submission.php 